\title{
Diálogos entre moda e literatura: uma análise sobre caracterização de personagem em Lucíola, de José de Alencar
}

Dialogues between fashion and literature: an analysis about characterization in Lucíola by José de Alencar

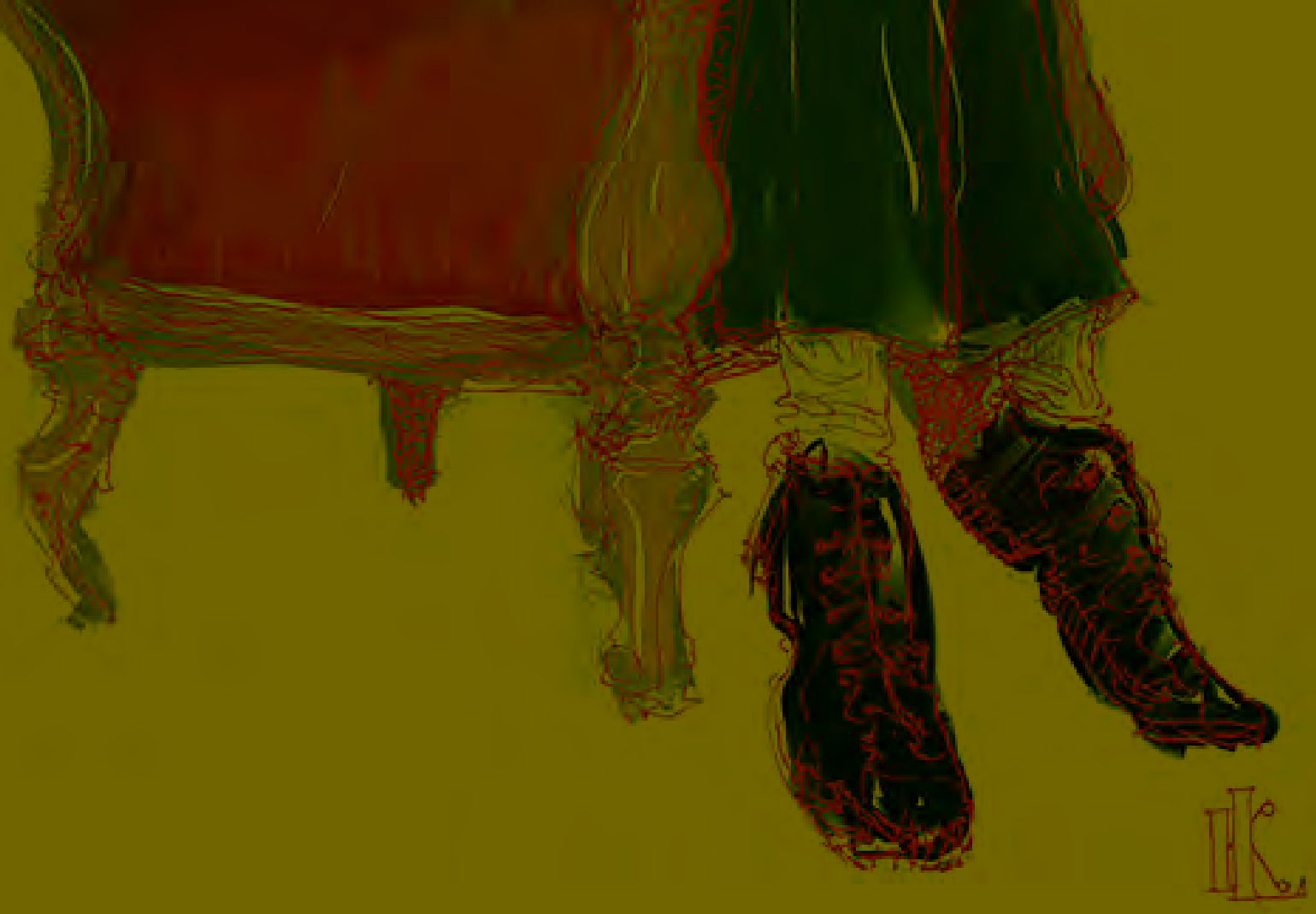


Javer Wilson Volpini ${ }^{1}$

ORCID: http://orcid.org/0000-0001-6823-4573

[resumo] Este artigo realiza um diálogo entre moda e literatura a partir do romance $\mathrm{Lu}$ cíola (1862), de José de Alencar. A literatura canônica desse escritor traçou um panorama minucioso do contexto social do século XIX e, no caso específico da obra em tela, retratou o cotidiano da corte imperial do Segundo Reinado no Brasil, oferecendo uma fonte de pesquisa de grande valor aos estudos acerca desse período que também pode ser expandida à investigação sobre moda. Refletindo sobre a construção de personagem no texto literário, foi possível analisar a importância da moda na narrativa do romance, exercendo papel fundamental para realizar a caracterização da protagonista, marcando sua dupla personalidade, da moça casta à mulher cortesã. Para isto, oferecemos um breve compilado das influências europeias na moda brasileira da corte do Segundo Reinado, externando uma ambientação social da época e relacionando-a com o contexto da narrativa literária. A moda, além de conferir verossimilhança ao enredo, também é usada pelo escritor como elemento literário de construção física e psicológica de sua personagem. Ao relacionar as descrições do vestuário no romance com as referências da moda da época, inferimos a importância do caráter simbólico que as roupas expressam também na construção social.

\section{[palavras-chave] Moda. Literatura. Lucíola. José de Alencar. Caracterização de personagem.}

[abstract] This study promotes a dialogue between fashion and literature in the novel Lucíola (1862) by José de Alencar. The writer's work presented a detailed panorama of $19^{\text {th }}$-century social context and, especially in this work, he portrayed the everyday life of Royal Court in Brazilian Second Reign, offering an important research source for studies of that period that can be expanded to investigate fashion. Taking into account the construction of characters in the literary text, it was possible to analyze the fundamental role played by fashion in the novel to define the characterization of the protagonist, stressing her double personality, from a chaste young lady to a sly courtesan. For that we offer a brief account of European influences on Brazilian fashion during the Second Reign, placing the social environment of the time and relating it to the context of the literary narrative. A side from assuring verisimilitude to the plot, fashion is also used by the writer as a literary device for the physical and psychological construction of the character. By relating descriptions of clothes in the novel to fashion references of the period, we imply the importance of symbolic meaning that clothing also expressed to social construction.

[keywords] Fashion. Literature. Lucíola. José de Alencar. Characterization.

Recebido em: 15-10-2019

Aprovado em: 03-12-2019

\footnotetext{
${ }^{1}$ Doutor em Letras - Estudos Literários pela Universidade Federal de Juiz de Fora. Professor e coordenador do Bacharelado em Moda do Instituto de Artes e Design da Universidade Federal de Juiz de Fora. E-mail: javervolpini@gmail.com. Lattes: http://lattes.cnpq.br/7602592532946679.
} 


\section{Introdução}

O traquejo para lidar com o vestuário e dominar as especificidades de sua linguagem foi uma característica marcante do Romantismo francês, no qual podemos sondar, de forma ilustrativa, por meio de grandes obras dessa literatura, um vasto repertório indiciário da moda como fator inerente ao processo da modernidade. Não é por acaso que Charles Baudelaire (1996) dedicou-lhe parte importante de suas reflexões em Sobre a modernidade, e também Honoré de Balzac, um capítulo inteiro em seus Tratados da vida moderna (2009), oferecendo, como ponto de partida para as nossas reflexões, a seguinte máxima: "O vestuário é a expressão da sociedade" (BALZAC, 2009, p. 77).

Temos na Escola Romântica brasileira autores como Joaquim Manuel de Macedo, José de Alencar e, mais tarde, entrando no Realismo, Machado de Assis, como expoentes máximos da tradição literária que recorreram à descrição dos trajes para oferecer verossimilhança às suas narrativas, contribuindo para os estudos da moda a partir do texto literário. Nesse contexto da literatura, entendemos a moda a partir de um conceito mais amplo, que extrapola a simples descrição de trajes, mas que incorpora a maneira do trajar, a postura, os costumes, a etiqueta e a gestualidade, como tradutora de todos os elementos que compõem os códigos sociais da época. A corte brasileira de meados do século XIX oferece o palco necessário para a expressão desse conjunto de manifestações da moda que Wanderley Pinho em Salões e damas do Segundo Reinado (1942) viria a questionar: "Mas que é a metade da vida, senão tudo isso?" (PINHO, 1942, p. 5).

Autores como Gilda de Mello e Souza, Gilberto Freyre, Maria do Carmo Rainho, Mariana Rodrigues e Geanneti Salomon debruçaram-se sobre a literatura do século XIX para travar um diálogo com a moda, utilizando os textos literários como registros daquela época. Nesse seguimento, e usando os estudos desses autores e de mais alguns, oferecemos neste artigo, sobre o romance Lucíola (1862), de José de Alencar, um diálogo entre moda e literatura sob uma perspectiva da moda como elemento de caracterização da personagem protagonista tanto física quanto psicologicamente.

Nesse texto literário, observamos que o uso de uma linguagem de caráter descritivo expressa um desejo do autor em criar uma ambientação, demarcar o tempo, construir um espaço e, ainda, caracterizar suas personagens. Esse referencial descritivo oferece um conjunto de informações importantes e necessárias à leitura do romance a fim de que haja uma contextualização da narrativa, tornando-o uma obra datada.

A partir dos códigos fornecidos pela própria narrativa, estabelece-se uma relação imagética entre o texto literário e o imaginário do leitor. Essas construções, no entanto, se constituirão de formas singulares, pois dependem basicamente do repertório cultural do receptor. Seus conhecimentos, a priori, atrelados a experiências que tangenciam uma cultura da visualidade, serão fatores determinantes para a construção desse imaginário. Esses fatores tornam-se mais importantes ainda quando tratam da descrição do vestuário, pois ela requer conhecimentos mais específicos da área da moda. 
Assim, relacionar moda e literatura para a construção desse repertório imagético infere em um trabalho de pesquisa que busca enunciados na obra literária que corroborem com a reflexão sobre o processo de caracterização das personagens. 0 diálogo que se pode perceber entre moda e literatura no romance Lucíola oferece uma compreensão da importância do vestuário como acessório da narrativa literária, contribuindo para a configuração da protagonista, ao longo da narrativa, em sua dupla personalidade: a moça casta e a cortesã.

\section{A roupa como caracterização da personagem}

Em um texto literário, observamos a construção das personagens de acordo com diversos tipos de características que lhes dão vida e identidade, situam-nas em determinado tempo e espaço e, principalmente, interferem no seu modo de ser e de agir dentro da narrativa. Segundo Yves Reuter, as personagens "permitem as ações, assumem-nas, vivem-nas, ligam-nas entre si e lhes dão sentido" (REUTER, 2007, p. 41). Dessa forma, muitas são as possibilidades de construção e de caracterização das personagens no texto literário, que vão desde as características físicas até as psicológicas. Fatores como idade, gênero, classe social, hábitos, costumes, entre outros, estabelecem uma mediação de construção da personagem entre o autor e o leitor, pois "a personagem, com efeito, é um dos elementos-chave da projeção e da identificação dos leitores” (REUTER, 2007, p. 41).

Entre as inúmeras possibilidades de caracterização, uma delas merece atenção especial neste artigo e se refere aos aspectos relacionados à roupa. Segundo Cláudia Duarte:

Historicamente, a literatura tem conferido à roupa uma importância primeira, como um código capaz de acessar conceitos, práticas, representações, como símbolo e recurso construtor de identidades sociais, culturais e de gênero. Ela sempre se valeu das roupas para dar substância aos seus personagens. (DUARTE, s/d, p. 1.062)

Na literatura romântica do século XIX, em geral, encontramos uma forte relação entre as personagens e os seus trajes. Isto infere em um grande acervo descritivo de modas, modos e demais aspectos do cotidiano da sociedade abastada do Brasil Imperial. "A indumentária ocupa um lugar de destaque na literatura brasileira, se valendo da marca psicológica ou social trazida pela roupa" (DUARTE, s/d, p. 1.063). De forma mais específica, na obra de José de Alencar, podemos nos valer da descrição dos trajes para esboçar um quadro da vestimenta da época.

Nosso foco, neste artigo, portanto, concentra-se nas descrições dos trajes da personagem-protagonista do romance Lucíola, de José de Alencar. Embora trate-se de um texto literário, não podemos desprezar sua contribuição como testemunho de uma época, haja vista os aspectos de verossimilhança que a moda oferece nessas narrativas, tornando-as um registro de seu tempo. Segundo Antonio Candido (2008), não se pode desprezar da crítica atual o seu interesse pelos diversos estudos de caráter social, realizados a partir da obra de arte, sem finalidades literárias. Assim, a literatura torna-se fonte fecunda para essas investigações e muitos romances, bem como outros contemporâneos do Romantismo brasileiro, 
foram consultados por diferentes áreas: não somente a sociologia, mas também a própria história, arquitetura, artes visuais, moda, entre outras, graças, principalmente, à riqueza da linguagem dos autores, de caráter descritivo dos cenários, costumes, regras de etiqueta, gestualidade e trajes que, por mais fictícios que se apresentassem dentro dos enredos, não fugiam às referências externas.

Um trabalho referente a esse tipo de estudo foi realizado por Mariana Rodrigues (2010), quando ela fez uma investigação sobre a moda no Rio de Janeiro oitocentista a partir da literatura brasileira do século XIX, tomando como fonte de pesquisa os romances de Joaquim Manuel de Macedo. De acordo com a autora,

\begin{abstract}
a literatura brasileira - cujo alcance se restringia à elite alfabetizada do país - ao lado dos diversos periódicos publicados na corte, torna-se um difusor de comportamento e de moda para um segmento da população que, embora possuidor de riqueza, situava-se à margem do mundo dito civilizado, mas que se apresentava sempre ávido em consumir e replicar os códigos de diferenciação adotados por seus contemporâneos europeus. (RODRIGUES, 2010, p. 20)
\end{abstract}

Autores como Machado de Assis e José de Alencar também serviram de fonte ao trabalho de Mariana Rodrigues que, segundo ela, confirmaram alguns pontos de vista suscitados ou, em outros momentos, observaram a moda por ângulos diferentes dos macedianos, oferecendo outros questionamentos.

Geanneti Salomon (2010) também pesquisou sobre a moda na literatura em um trabalho sobre a obra Dom Casmurro, de Machado de Assis. Essa autora analisa a moda no texto literário

como um fenômeno semiológico, histórico e sociológico, capaz de apontar características culturais e sociais de um determinado povo e, mais profundamente, também capaz de demarcar o tempo, expor aspectos da personalidade das pessoas e da época em que viveram, explicitando ainda alterações em suas personalidades ao longo de suas existências, e servindo, assim, à construção literária. (SALOMON, 2010, p. 18)

Gilda de Mello e Souza (2009) foi uma das pioneiras em relacionar moda e literatura na década de 1950. A partir da literatura brasileira desenvolveu seu trabalho sobre a moda no século XIX. Ela afirma que esse tipo de estudo, visto apenas pelo viés imagético, acaba tornando a análise um pouco estática, portanto, valeu-se dos textos sociológicos, das crônicas de jornais da época e, principalmente, "do testemunho dos romancistas, cuja sensibilidade aguda capta melhor que ninguém, nos meios elegantes, o acordo da matéria com a forma, da roupa com o movimento, enfim, a perfeita simbiose em que a mulher vive com a moda" (SOUZA, 2009, p. 24).

Por meio dos códigos do vestir e das descrições dos trajes realizados pelos escritores em seus romances, é possível criar um imaginário de identificação da personagem com o leitor e situá-lo dentro do contexto histórico e do enredo da obra. Dessa forma, duas datas 
são importantes para as nossas análises: os anos 1855 e 1862. A primeira está marcada em Lucíola como o início da história, e a segunda refere-se à escrita e à publicação do romance. Visualizamos, assim, um período de oito anos, dentro das décadas de 1850 e de 1860, muito importante para a moda no século XIX, mas que, no entanto, vivenciam os mesmos hábitos e costumes do vestir. Trata-se do período que ficou conhecido como Era Vitoriana na Europa e que exerceu fortes influências no vestir tropical das classes mais abastadas e da aristocracia do Segundo Reinado na corte do Rio de Janeiro, local onde foi ambientado o romance de José de Alencar. Salientamos que o Segundo Reinado no Brasil esteve sob a regência de D. Pedro II e compreendeu o período de 1840 até 1889, com a queda da monarquia e a Proclamação da República. Foi uma época de grandes transformações econômicas, sociais e culturais, impactando significativamente a sociedade brasileira. A fim de averiguar as relações de contextualização no romance, realizaremos uma breve explanação sobre a moda desse período e suas influências no Rio de Janeiro para, posteriormente, identificarmos as relações e a importância de seus artefatos para a construção e a caracterização da personagem no romance.

\section{Influências europeias na moda da corte brasileira}

A moda europeia começa a exercer influência no Brasil Colônia a partir de 1808 com a chegada da corte portuguesa. Antes, o Rio de Janeiro assemelhava-se mais a uma aldeia que, segundo Maria do Carmo Rainho, "era um espaço identificado com o 'atraso', muito mais próxima dos primórdios da colonização do que das mudanças que, em dez anos, alterariam a sua face e os costumes de seus habitantes" (RAINHO, 2002, p. 48).

Após a chegada da família imperial portuguesa, observamos um processo de profundas transformações em todos os setores da vida social, cultural e econômica, refletindo alterações, principalmente, nos hábitos, nos costumes, nos espaços urbanos e, consequentemente, no vestir. "No Rio de Janeiro, as transformações no espaço urbano, a europeização dos costumes, o incremento do comércio e a intensificação da vida social são os elementos que servem de pano de fundo para a difusão da moda" (RAINHO, 2002, p. 14). Essa "europeização" faz referência, principalmente, à necessidade de eliminação dos ares coloniais impostos com a chegada da corte portuguesa. Esse momento sinaliza, em muitos aspectos, as mudanças de comportamento da colônia, que entrará em um período de profundas adaptações.

Uma segunda fase desse processo de transformação, que contextualiza o foco desta investigação, acontece a partir de 1850, quando se inicia um período de modernização na cidade do Rio de Janeiro. Nas palavras de Rainho, podemos exemplificar esse desenvolvimento urbano com “a introdução das ferrovias na década de 1850 , as benfeitorias no porto da cidade, a reestruturação dos sistemas de água e esgotos, a inauguração da iluminação a gás, a formação das companhias de carris, com a introdução dos bondes" (RAINHO, 2002, p. 58), entre outros fatores.

Ainda atrasados em relação ao desenvolvimento da Europa, principalmente no que se refere aos avanços tecnológicos da Revolução Industrial, o Brasil, sob a influência dos industriais ingleses, entra em um período de recuperação do tempo perdido, rumo ao progresso. Todo esse processo se refletirá profundamente na moda do Brasil, já independente 
de Portugal desde 1822, e, assim, a sua difusão esteve especialmente relacionada ao desenvolvimento urbano.

As referências em todos os setores, principalmente os culturais, vinham diretamente da Europa e com a moda não foi diferente. Ela entra na lista das preocupações da corte para a sua exibição na intensa vida social - os passeios pelas ruas, os cafés nas confeitarias, os saraus, os bailes, os teatros e demais acontecimentos -, usando o que havia de mais parecido com as novidades da moda europeia. Assim, "era imprescindível reproduzir os padrões europeus de vestimenta e, em especial, os modelos usados na França” (RAINHO, 2002, p. 15).

Não só a moda era importada, mas também os ideais que ela simbolizava. Durante o Segundo Reinado no Brasil, "copiavam-se os esplendores do Segundo Império em França. Paris dominava ainda uma vez o mundo [...]. O Rio de Janeiro contagiava-se da imitação. A alegria meridional da Imperatriz Eugênia talhava modelos" (PINHO, 1942, p. 99).

Assim, a moda torna-se o instrumento apropriado para externar os códigos de prestígio e de poder. Às mulheres, portanto, era necessário um guarda-roupa variado e caro, afinal, "de seu comportamento social, de seus vestidos e joias, de sua maneira de receber e de se insinuar junto a personagens de prestígio dependia o bom encaminhamento da carreira política ou econômica do marido" (MURICY, 1998, p. 57).

Gilberto Freyre também se expressou a respeito disso. Segundo ele:

É preciso que os vestidos de esposas ou de filhas variem, de menos a mais exuberantemente caros, e adornados como expressão, quer da constância de status alto dos maridos e pais, quer como expressão de aumento de prosperidade ou de ascensões socioeconômicas ou políticas ou na ocupação de cargos ilustres dos mesmos maridos ou pais. Ou, em alguns, de amantes de homens que se sintam comprometidos, por motivos de prestígio social, a se afirmarem através de vestidos, adornos, sapatos ostentados por suas - no caso - amantes. (FREYRE, 2009, p. 53)

A maior divulgação da moda no Brasil deu-se pelas revistas, pelos jornais e pelos demais periódicos, que entre outros assuntos, dedicavam colunas especialmente à toalete das damas da época. Alguns desses periódicos já existiam desde a década de 1820, porém, foi a partir de 1850 que essas publicações se intensificaram e, em muitas delas, junto de literatura, política, artes, teatro, entre outros assuntos, a moda também recebia um lugar de destaque.

Os principais periódicos que circularam no Império durante o Segundo Reinado, no que diz respeito à moda, quase que por unanimidade restringiam-se à divulgação da moda francesa, com gravuras ilustrativas e suas descrições minuciosas ou, em outras oportunidades, detalhando o que se usava na corte, difundindo assim, não somente a moda, mas principalmente o que ela representava em termos de estabelecimento de posições sociais.

Em outros veículos, não de divulgação da moda, mas nos quais ela aparece inserida em um contexto de observações, foram os romances de folhetins, caracterizados como romances de costumes e também romances urbanos, que, no caso dos de José de Alencar, povoaram o imaginário da boa sociedade e acabaram por influenciar os modos da corte, ora corroborando com os códigos vigentes, ora, em outros momentos, fazendo críticas severas às relações 
estabelecidas no Brasil daquela época. Entre autores expoentes na literatura desse gênero, temos os já citados Joaquim Manuel de Macedo, José de Alencar e Machado de Assis, como seus principais representantes.

No intuito de estabelecer uma identificação de verossimilhança dentro dessas obras, a moda converte-se em um forte componente de construção das personagens. "A moda transforma-se num objeto a ser registrado, analisado e discutido. Torna-se digna da atenção de inúmeros romancistas, como José de Alencar e Machado de Assis" (RAINHO, 2002, p. 67). Será sob essa vertente do diálogo entre moda e literatura em Lucíola que desenvolveremos as nossas análises a partir da próxima seção deste artigo.

\section{A moda como acessório da narrativa em Lucíola}

No romance Lucíola, observamos como as relações externas influenciaram a criação da obra literária. José de Alencar oferece um retrato bem detalhado da corte brasileira do Segundo Reinado utilizando muitos recursos da verossimilhança. Entre eles, podemos destacar os tipos de suas personagens, os espaços urbanos de circulação, a ambientação, as referências da cidade e, principalmente, a temática de sua obra: a história de uma cortesã.

Não se trata, porém, de uma simples cortesã, como conhecemos muitas ao longo da história, mas uma cortesã que tenta se redimir por meio do amor. Essa personagem complexa acaba por se inserir profundamente na sociedade da época quando vivencia suas duas faces: a casta Maria da Glória, em um primeiro momento, moça simples e frágil que virá a ser corrompida, fazendo parte de uma parcela da população numerosa, mas pouco expressiva pela sua condição social. Posteriormente, a mesma Maria da Glória redimida da condição de cortesã, mas com um histórico de experiências de relações com a boa sociedade, por causa do seu trânsito pela corte. E, por último, a personagem Lúcia, a cortesã, que condiciona tudo o que leva à redenção de Maria da Glória. Essa segunda face apresenta uma personagem que experimentou todo o luxo e a ostentação da corte, circulando pelos mais altos e importantes meios da boa sociedade do Segundo Reinado: ora acompanhada de seus protetores ou, em outros momentos, em busca de novos amantes.

Dessa forma, observamos uma ambiguidade sempre presente em toda a obra, contrapondo os perfis da personagem em seu duplo - moça casta versus cortesã. Para construir essa personagem, José de Alencar valeu-se, entre outros acessórios narrativos, das descrições dos trajes, servindo-lhe a moda do período, além de enunciado descritivo de uma coletividade, também de traços marcantes da contraditória individualidade da protagonista. "Da temática romântica da cortesã, ela retoma, de modo condensado, as contradições entre virtude e vício, alma e corpo, ingenuidade e devassidão, amor e prazer, família e prostituição" (DE MARCO, 1986, p. 156).

Podemos visualizar, no romance, que o uso das roupas, como o conhecemos historicamente, oferece um marcador de correlações indicativas de posição social, quando "a boa sociedade fluminense manifestava, por meio do vestuário, o quanto se distinguia dos outros estratos da sociedade" (RAINHO, 2002, p. 15). Por meio das roupas, podemos ainda identificar perfeitamente uma senhora de família, uma mocinha da sociedade e, também, uma cortesã. Embora quem esteja usando cada roupa possa não desempenhar os papéis 
elucidativos de seus trajes. Isto pode ser observado no romance quando Lúcia é vista como uma senhora aos olhos de Paulo por causa dos seus trajes, pelo seu comportamento e pela sua postura. "- Quem é esta senhora? - perguntei a Sá. [...] - Não é uma senhora, Paulo! É uma mulher bonita. Queres conhecê-la?" (ALENCAR, 2010, p. 17). Somente após a observação de Sá que Paulo se dá conta do que significava "mulher bonita”. Em pensamento, posteriormente, Paulo ainda não se conformava que aquela senhora pudesse ser uma cortesã, pois "a expressão cândida do rosto e a graciosa modéstia do gesto, ainda mesmo quando os lábios dessa mulher revelavam a cortesã franca e impudente” (ALENCAR, 2010, p. 18), não combinavam com a imagem de senhora que ela comunicava. Veremos, portanto, ao longo do romance, que os artefatos de moda oferecem a Alencar o subsídio necessário para a construção da protagonista, expressando seus diversos momentos de passagem no trânsito conflituoso entre as ocasiões da personagem como Lúcia e como Maria da Glória.

Ainda no início da narrativa, quando a imagem de Lúcia, na festa da Glória, surge pela primeira vez aos olhos de Paulo e ele a confunde com uma senhora, sua descrição é feita paralelamente aos detalhes do seu vestido e ao porte elegante de dama da sociedade: "Admirei-lhe do primeiro olhar um talhe esbelto de suprema elegância. 0 vestido que o moldava era cinzento com orlas de veludo castanho e dava esquisito realce a um desses rostos suaves, puros e diáfanos [...]" (ALENCAR, 2010, p. 17). Assim, Valéria de Marco defende o uso da roupa como composição do texto:

\footnotetext{
Quanto ao segundo procedimento - o de explorar as possibilidades de significação dos componentes acessórios da narrativa - o episódio da Glória já nos adverte de que devemos dar especial atenção à descrição das roupas de Lúcia e dos espaços em que se desenvolve a ação. Frequentemente, esses elementos catalisam os movimentos narrativos. Dramaticamente, eles ocultam ou revelam desejos e sentimentos das personagens. No cenário da festa religiosa, Lúcia entra coberta pela discrição do cinza. Do alto da Glória, Paulo tem um quadro vivo da cidade em ação. Mas a frase de Sá desfaz a ilusão e revela por um lado, o desejo de Lúcia de ocultar momentaneamente a cortesã e, por outro lado, a ignorância do provinciano. (DE MARCO, 1986, p. 157)
}

A riqueza descritiva dos trajes em Lucíola possibilita relacionar a estreita ligação da moda com o universo das cortesãs, visto que essas personagens sempre foram referência para a moda de sua época. Isto não somente por difundirem o que se usava, ao se apresentarem sempre bem vestidas, mas, principalmente, em alguns momentos, por serem as responsáveis pelo lançamento da própria moda, podendo ser consideradas como vanguarda de seu tempo. Suzan Griffin apresenta um extenso trabalho sobre a história das cortesãs no qual é possível observar a relação dessas personalidades com a moda no século XIX.

O esplendor em que viviam as cortesãs é lendário. Às vezes as suas fortunas chegavam a exceder a de seus protetores. Elas acumulavam casa na cidade, châteaux, villas, tudo decorado com afrescos e esculturas de grandes pintores (...) Suas carruagens rivalizavam com as exibidas pela elite. Seus guarda-roupas, guarnecidos 
com modelos feitos com os tecidos mais luxuosos e pelos costureiros mais famosos - Charles Worth, por exemplo, ou Paul Poiret - eram invejados por mulheres respeitáveis e com títulos de nobreza, que copiavam o seu estilo de vestir. E, acima de tudo, as cortesãs colecionavam jóias: colares de diamantes e pérolas, tiaras de diamantes, anéis de safiras e rubis, broches de esmeraldas, que ostentavam com grande orgulho e também naturalidade. (GRIFFIN, 2003, p. 19)

Nessa citação, podemos inferir que a questão da vestimenta é fator determinante na caracterização das cortesãs, portanto, indispensável à construção de uma personagem inspirada nessas mulheres. Salientamos, além disso, a referência a Worth, nome pioneiro da moda autoral na segunda metade do século XIX. Estreitando, ainda, as relações do Brasil com a França, nesse momento da história do Brasil, reportamo-nos também a Charles Baudelaire, poeta francês do século XIX, que ofereceu muitas contribuições acerca da moda do seu tempo, trazendo também alguns registros sobre as cortesãs.

Mulheres que exageraram a moda, a ponto de lhe alterar a graça e lhe destruir a intenção, varrem faustuosamente os soalhos com a cauda de seus vestidos e a ponta de seus xales; vão e vêm, passam e repassam, abrindo os olhos espantados como os dos animais, dando a impressão de nada verem, mas examinando tudo. Sobre um fundo de luz infernal ou de aurora boreal, vermelho, alaranjado, sulfuroso, rosa (o rosa revela uma ideia de êxtase na frivolidade), algumas vezes violeta (cor preferida das abadessas, brasa que se apaga por trás de uma cortina de azul), sobre esses fundos mágicos, imitando diversamente os fogos de Bengala, eleva-se a imagem variada da beleza equívoca. Aqui majestosa, lá delicada; ora esbelta, franzina até, ora ciclópica; ora pequena e vivaz, ora pesada e monumental. Ela inventou uma elegância provocante e bárbara, ou então aspira, com maior ou menor felicidade, a simplicidade de praxe na melhor sociedade. Caminha, desliza, dança e rodopia com seu peso as crinolinas bordadas que lhe servem ao mesmo tempo de pedestal e de contrapeso. Lança o olhar por debaixo do chapéu, como um retrato em sua moldura. (BAUDELAIRE, 1996, p. 62)

Interessante ressaltar outra referência de moda encontrada na citação de Baudelaire em relação às crinolinas. Elas representaram a grande marca da moda vitoriana. "A crinolina com toda certeza, não era um traje virtuoso, e a época que atingiu seu maior desenvolvimento, o Segundo Império Francês, não foi uma época de muita moralidade. A história social do Segundo Império é a história da grande cocotte" (LAVER, 2008, p. 185). A crinolina usada no período vitoriano aparece também em Lucíola como aparato do vestuário. Vejamos a situação em que ela é descrita no romance:

Figure uma moça vestida de ricas sedas, com as mangas enroladas e a saia arregaçada e atada em nós sobre o meio da crinolina; com uma toalha passada ao pescoço à guisa de avental; vermelha pelo calor e reflexo do fogo, batendo gemas de ovos para fazer não sei que doce. Repito: era preciso ter a faceirice e gentileza 
daquela mulher, para nessa posição e no meio da moldura de paredes enfumaçadas, obrigar que a admirassem ainda. Fui tirá-la da sua azáfama doceira, e a trouxe confusa e envergonhada. Depois que ela reparou a desordem de seu traje, tanto quanto era possível, tomei-lhe contas severas. (ALENCAR, 2010, p. 103).

Na citação, registramos o embaraço que era o uso da crinolina e de todos os trajes que a sobrepunham, restringindo a mulher no realizar de muitas atividades domésticas, cabendo essa tarefa às criadas. "A ociosidade aristocrática era vista como um modo de vida apropriado para mulheres de classes média e alta. As roupas da moda, portanto, eram inapropriadas para as atividades diárias da maioria das mulheres de classe operária" (CRANE, 2009, p. 70).

Observamos, nos trechos do romance a seguir, a supervalorização dos acessórios da narrativa quando, em alguns momentos, a personagem materializa-se pelos trajes que usa. Quando Lúcia questiona Paulo se ele lembrava-se dela, de seu encontro anterior, a primeira cobrança é a recordação de sua toalete: “- Que vestido levava eu naquela tarde?” Paulo, por não se lembrar, justifica: "Não reparo na toilette das moças bonitas pela mesma razão que não se repara na moldura de um belo quadro." Lúcia, no entanto, descreve-o pelo traje que usava: "E eu por que reparei no seu traje, na cor de sua sobrecasaca, em tudo; até na sua bengala? Não é esta; a outra era mais bonita; tinha o castão de marfim. Está vendo que me lembro perfeitamente, e entretanto não tenho esses objetos diante dos olhos!" Paulo, então, pergunta se o vestido que ela usa é o mesmo. Lúcia afirma: “- 0 vestido, as joias, o penteado, o leque, aquele que o senhor apanhou. Nem desse se lembrava! Faltou o chapéu! Quer vê-lo?" Ela busca o chapéu e Paulo afirma que a vê como da primeira vez. Ela finaliza: “- Como daquela vez não me verá nunca mais!” (ALENCAR, 2010, p. 26).

Nesse trecho, podemos apontar o vestuário inferindo diretamente na composição das personagens. Para Lúcia, em um primeiro momento, Alencar utiliza seus trajes para contextualizar a imagem de moça pura e de boa sociedade que Paulo tivera de sua pessoa. Depois, entra em cena a cortesã - o lado psicológico da personagem - que, ainda que trajando as mesmas roupas, não é mais a moça casta que se encontra à frente de Paulo.

Outro atributo enfático na fala de Lúcia refere-se ao leque: "Nem desse se lembrava!" (ALENCAR, 2010, p. 26). Ela fala do primeiro encontro dos dois na Rua das Mangueiras, quando Paulo a vê passar em "um carro elegante que levavam a trote largo dois fogosos cavalos" (ALENCAR, 2010, p. 19). Assim Paulo a descreve:

Uma encantadora menina [...] deixava pender pela cobertura derreada do carro a mão que brincava com um leque de penas escarlates. Havia nessa atitude cheia de abandono muita graça; mas graça simples, correta e harmoniosa; não desgarro com ares altivos decididos, que afetam certas mulheres à moda. (ALENCAR, 2010, p. 19)

Esse mesmo leque cai das mãos de Lúcia em um movimento brusco da carruagem e Paulo tem a oportunidade de se aproximar para devolvê-lo. Haverá outras passagens, ao longo da narrativa, nas quais o leque assume uma conotação simbólica, fazendo referência 
também às questões da gestualidade. "Quanto a Lúcia, fazendo-nos um ligeiro aceno com o leque, aproveitou uma abertura da multidão e penetrou no interior da igreja [...]" (ALENCAR, 2010, p. 18). Vejamos, ainda, as lembranças de Paulo sobre uma aparição de Lúcia no teatro, quando o leque assume uma posição importante, mais do que a própria roupa.

Não me posso agora recordar das minúcias do traje de Lúcia naquela noite. 0 que ainda vejo neste momento, se fecho os olhos, são as nuvens brancas e nítidas, que se frocavam graciosamente, aflando com o movimento de seu leque; o mesmo leque de penas que eu apanhara, e que de longe parecia uma grande borboleta rubra pairando no cálice das magnólias. (ALENCAR, 2010, p. 31)

Apontamos, portanto, como certos acessórios de moda contêm uma carga simbólica muito forte dentro da narrativa, especialmente quando observados como indícios de referência cultural de uma determinada época. A respeito do leque, o jornal $O$ Espelho, de 1859, apresenta algumas considerações que extrapolam seu uso para o simples ato de abanar-se por causa do calor.

0 teatro estava cheio na primeira noite, domingo, os camarotes irradiavam com as belezas que molemente se reclinavam lá - à espera da ansiada representação. Como era intenso o calor - andavam os leques em contínua agitação. É uma bela invenção o leque. É uma qualidade de mais que a arte consagrou à mulher. Meu Deus! 0 que tem feito o leque no mundo! Muitos romances nesta vida começam pelo leque, a tranquilidade de um esposo ou de um pai tem nascido muitas vezes do manejo calculado de um leque. Mas também é uma arte o estudo de abrir e fechar este semicírculo dos salões e dos teatros. Um bom fisiologista conhece o caráter mais impenetrável pelo modo de agitar o leque. Sou realmente capaz de apostar, diz Mme. de Sevigné, que em todos os atrativos da mulher mais elegante e casquilha, não há atavios de que ela possa tirar partido como o leque. (M-AS, 1859, p. 8)

Usado desde a Antiguidade, o leque adquiriu outras funções ao longo da história, assumindo, na corte francesa de Luís XIV, a função de transmissor de mensagens simbólicas entre namorados e amantes. Assim, seu uso no século XIX, estava ligado também a essas conotações. Gilberto Freyre (1964) apresenta um trecho que oferece um depoimento sobre a utilização do leque para os galanteios no século XIX. Uma senhora explica-lhe que "tudo dependia do modo de pegar o leque". Isto era afirmado apresentando inúmeras maneiras de manejo dos movimentos com o acessório "para ilustrar as recordações daquele modo como que maçônico e, com certeza, secreto, de utilizar-se uma sinhazinha do complemento aparentemente tão sem importância da graça feminina de outrora”. Assim, de acordo com Freyre, as mocinhas expressavam, por meio do leque, "uma linguagem particular de amor que todos os namorados deviam conhecer". O leque fechado dizia: "cuidado, nos observam"; o leque aberto imóvel: "o terreno está livre"; o abano forte do leque: "amo-te muito"; e assim por diante (FREYRE, 1964, p. 118). 
Outros componentes da moda da época foram as luvas, que simbolizavam primordialmente status social. Em Lucíola, a personagem cortesã aparece constantemente usando esse acessório: "Na ocasião de entregar o leque apertei-lhe a ponta dos dedos presos na luva de pelica" (ALENCAR, 2010, p. 20). Em outro momento, no teatro, segurando um binóculo: "Depois, ao levantar o pano, vi Lúcia naquela direção, e pareceu-me reconhecer nela a indiscreta luva cor de pérola e o curioso instrumento que me perseguira com o seu exame" (ALENCAR, 2010, p. 21). Antes de sair para um baile, "a mucama lhe apresentava as luvas e o leque, o mesmo do nosso primeiro encontro, e que ela costumava trazer sempre" (ALENCAR, 2010, p. 81). Após um encontro com um de seus amantes, a luva aparece com uma simbologia de proteção: "Aquele homem não tocou no meu corpo, porque até a mão que roçou na sua, estava calçada com esta luva, que eu já despedacei" (ALENCAR, 2010, p. 87). No romance, haverá outras passagens em que as luvas se apresentam como parte fundamental da toalete, especialmente em ocasiões de eventos sociais.

Vejamos, novamente, o que diz o jornal $O$ Espelho em uma de suas crônicas a respeito do uso das luvas.

\footnotetext{
Não há moça de mão delicada, nem rapaz do tom, que deixe de trazer a sua luva de pelica. É possível em um baile encontrar-se alguma moça com os braços descobertos, com o cabelo sem enfeite, com o colo despido, com um vestido simples, porém com as mãos nuas, sem luvas, isso não, é coisa que não se vê, nem em qualquer casa, em que haja uma simples contradança. A luva, pois, é tão necessária para quem vai ao baile, como é preciso o lenço para quem tem defluxo. Na verdade, a mão mimosa e pequenina, como a de uma boneca, coberta com uma luva de pelica, que fique justa aos dedos, parecendo constituir uma nova pele formada pela arte, adquire tanta graça, tanto feitiço, que obriga, às vezes, a meia dúzia de namorados a andar de beiço caído e de cabeça tonta. (AZEVEDO, 1859, p. 7)
}

Temos, então, o leque, as luvas, os chapéus, as sombrinhas, as joias, a renda, a seda e as roupas como parte dos elementos da narrativa que irão, além de compor a protagonista, contextualizar sócio, histórica e culturalmente o enredo de Lucíola, oferecendo aos leitores um panorama da moda no Rio de Janeiro daquele período que, embora sendo uma cidade de clima tropical, seus habitantes insistiam em se vestir como os europeus, de forma especial, os parisienses. Para Freyre, isto se tratava de "abusos, em pleno Rio de Janeiro, de modas, para mulheres, de capas de peles para invernos franceses, de luvas, de outras defesas contra excessos europeus de frio, de neve, de gelo" (FREYRE, 2009, p. 175).

Assim, nessa contextualização, temos também a Rua do Ouvidor como local de disseminação da moda parisiense, onde era possível encontrar todos os tipos de artigos que compunham a toalete da mulher. Essa importante rua da cidade do Rio de Janeiro foi denominada de "rainha da moda, da elegância e do luxo" (MACEDO, 1988, p. 54), por Joaquim Manuel de Macedo, ou na poética descrição feita pelo periódico $O$ Espelho:

[...] e para não faltarmos a um dos fins que nos propusemos, não há outro remédio senão irmos até à rua do Ouvidor, que sem mais nem menos, é a rua Rivoli 
de Paris. A nossa rua do Ouvidor já pode dar que falar a qualquer parisiense recém-chegado. A elegância e a beleza deram-se as mãos e dela fizeram um paraíso terreal. É o rendez-vous do belo. 0 aristocrata e o burguês, o estudante e o caixeiro não podem reprimir o murmúrio de prazer que lhes paira nos lábios quando avistam esse assédio da meiguice e da moda. (CRÔNICA, 1859, ed. 1, p. 10)

A Rua do Ouvidor era a rua da moda no Segundo Reinado no Brasil e continuou sendo por muitas décadas após esse período, sendo referência também no século XX. Era nessa rua que se concentravam as lojas de artigos luxuosos vindos da Europa. Ponto de estabelecimento de modistas francesas, alfaiates ingleses, sapateiros, chapeleiros, joalheiros e tudo mais que se referisse à moda do período, tanto masculina como feminina. Também eram essas lojas a opção de trabalho para muitas mulheres, "as caixeirinhas, jovens brasileiras de cor que, afrancesadas, sabiam vender, a brasileiras ilustres, artigos de modas francesas, chegados de Paris" (FREYRE, 2009, p. 241). Assim, veremos que no romance de Alencar, a Rua do Ouvidor é por diversas vezes citada. Era ponto de encontro da sociedade fluminense, onde Paulo vira Lúcia em algumas situações, que, entre outras passagens, estava a cortesã fazendo compras, acompanhada de seu amante, Couto. "[...] todas as pessoas presentes ficaram persuadidas que da bolsa do velho saía o dinheiro que ela acabava de atirar a mancheias de uma a outra ponta da Rua do Ouvidor" (ALENCAR, 2010, p. 75).

Lúcia é uma personagem que evidencia o retrato da mulher abastada - embora cortesã -, que desfrutava de todos os requintes ofertados pela sociedade da corte. Sua toalete seguia rigorosamente todas as influências parisienses, e sua figura apresentava a postura e a elegância de uma verdadeira dama. Como uma burguesa europeia, também se exibia por meio de suas posses.

\footnotetext{
Vou mandar a cocheira ver o meu carro; escrever à Gudin que me faça uma dúzia de vestidos os mais ricos; dizer ao caixeiro do Wallerstein que me traga para escolher o que ele tem de melhor em modas chegadas ultimamente! É verdade, esquecia-me de mandar tomar uma assinatura no teatro lírico, e encomendar uma nova parelha de cavalos. A minha caleça já está usada; preciso trocá-la por uma vitória, e renovar o fardamento dos criados. (ALENCAR, 2010, p. 73)
}

Gudin foi uma modista francesa, instalada na Rua do Ouvidor, que tinha as princesas imperiais do Brasil como clientes. Por essa razão, "seu estabelecimento ultrapassou em muito o estágio de simples oficina de costuras para tornar-se local onde podiam ser encontrados não apenas luxuosas fazendas, mas também os indispensáveis acessórios e produtos de toucador" (MENEZES, 2004, p. 14).

Em Memórias da Rua do Ouvidor (1988), Joaquim Manoel de Macedo considera Wallerstein como o "Napoleão da moda e da elegância". A seu respeito, este autor fala que "a lembrança dos seus primores faz ainda palpitar corações, não de velhas, porque não há senhoras que o sejam, mas de senhoras que foram meninas e jovens durante o florescimento daquele gênio do bom-gosto" (MACEDO, 1988, p. 113). Esse famoso personagem da moda fluminense era como Worth, em Paris. Tudo o que vinha dele imediatamente era copiado por toda a corte. 
Era preciso que a mulher burguesa estivesse sempre bem vestida, pois, como já dissemos anteriormente, na boa sociedade, ela era incumbida de externar, por meio dos seus trajes, das suas joias e, acima de tudo, da sua postura e da sua elegância, a posição econômica e familiar concedida por seu marido. Com a cortesã não era diferente, por meio do luxo que ostentava, demonstrava a sua importância e os ricos amantes que colecionava. "Nunca lhe faltam amantes; sei de grandes fortunas no Rio de Janeiro que se dariam por felizes se ela se decidisse a arruiná-las" (ALENCAR, 2010, p. 33). E é assim, para caracterizar essa personagem tão própria da corte, que Alencar utiliza com maestria da moda como acessório importante da narrativa.

Veremos, portanto, algumas passagens em que as descrições do traje compõem o espírito da personagem. Abaixo, Lúcia arruma-se para acompanhar seu amante Couto em um baile:

[...] chegou-se ao espelho para dar os últimos toques ao seu traje, que se compunha de um vestido escarlate com largos folhos de renda preta, bastante decotado para deixar ver suas belas espáduas, de um filó alvo e transparente que flutuava-lhe pelo seio cingindo o colo, e de uma profusão de brilhantes magníficos capaz de tentar Eva [...]. Uma grinalda de espigas de trigo cingia-lhe a fronte e caía sobre os ombros com a basta madeixa de cabelos, misturando aos louros cachos aos negros anéis que brincavam. (ALENCAR, 2010, p. 77)

Essa descrição, a mais exuberante no romance, caracteriza, entre outras, a forma como a mulher se produzia para os bailes. A cor escarlate do traje, a ênfase no grande decote e o uso dos brilhantes servem de aparato para externar a imagem da cortesã, que, aos olhos da personagem, de acordo com Alencar (2010, p. 78) "ornavam-se as vítimas para o sacrifício". "Dela é impossível fugir, pois Alencar explora cuidadosamente o corpo de Lúcia, seu perfume e suas roupas para desfazer o equívoco do provinciano" (DE MARCO, 1986, p. 184).

A respeito dessa mesma descrição dos trajes de Lúcia - agora totalmente em desalinho -, veremos como o autor utiliza-se desse recurso, em uma versão pós-festa, para acentuar o estado de espírito da personagem desolada pelo ciúme que sentira de Paulo:

Tinha o mesmo vestido de seda escarlate que levara ao teatro, porém amarrotado, com as rendas despedaçadas e os colchetes arrancados da ourela, onde se viam os traços evidentes das unhas. Os cabelos em desordem flutuavam sobre as espáduas nuas; a grinalda despedaçada, o leque e as luvas jaziam por terra; numa cadeira ao lado estavam amontoadas todas as suas joias. (ALENCAR, 2010, p. 85)

Em contrapartida, veremos outros momentos, por meio das roupas, em que o espírito "casto e ingênuo" sobrepõe-se ao corpo vil da cortesã, podendo ser observado a partir de pequenos gestos e atitudes, relacionados à descrição de seu traje. "A gola de seu roupão azul abriu-se com um movimento involuntário, deixando ver o contorno nascente de um seio branco e puro, que o meu olhar ávido devorou com ardente voluptuosidade" (ALENCAR, 2010, p. 22). A atitude de Lúcia em relação ao olhar malicioso de Paulo foi enrubescer-se como uma menina e fechar o roupão, com um gesto delicado, sem nenhuma pretensão. 
Outra observação de importância da moda no processo da caracterização mais psicológica da personagem pode ser verificada em uma cena do teatro, quando Lúcia estava "vestida com certa galantaria, mas sem a profusão de adornos e a exuberância de luxo que ostentam de ordinário as cortesãs" (ALENCAR, 2010, p. 31). Nessa passagem, a descrição do traje, com a ausência do extremo luxo, tenta anular a imagem da cortesã e aproximá-la de uma dama da "boa sociedade". Assim, é possível assinalar, mais uma vez, como o autor recorre aos artifícios da roupa e acrescenta que "a expressão angélica de sua fisionomia naquele instante, a atitude modesta e quase tímida, e a singeleza das vestes níveas e transparentes, davam-lhe frescor e viço de infância, que devia influir pensamentos calmos, senão puros" (ALENCAR, 2010, p. 32). As vestes aqui também evidenciam o lado da alma de Lúcia que, em conflito com o lado carnal da cortesã, indicará, ao longo do romance, a pureza casta de Maria da Glória.

Mais um exemplo pode ser observado quando Lúcia recebe Paulo para um jantar em sua casa e se arruma de forma simples, mas com muito esmero. "Estava encantadora com o seu roupão de seda cor de pérola ornado de grandes laços azuis, cuja gola cruzando-se no seio deixava-lhe apenas o colo descoberto. Nos cabelos simplesmente penteados, dois cactos [...]" (ALENCAR, 2010, p. 57). Tratava-se de um jantar informal, e como observa o narrador, ela fez "as honras de sua casa como uma verdadeira senhora" (ALENCAR, 2010, p. 57).

Com o envolvimento de Lúcia e a paixão que vai surgindo por Paulo, vamos observando que a cortesã, aos poucos, começa a se purificar, dando lugar ao lado espiritual da moça Maria da Glória. Mais uma vez, registramos a importância do traje como marcador desses momentos de passagem: "Olhe para mim. Quando eu despir esta roupa, despirei trapos que para nada servem!” (ALENCAR, 2010, p. 87). Na continuidade desse trecho, Lúcia entra para o banho e volta pura e casta para Paulo. Como a fênix que renasce das cinzas, ela apresenta-se à apreciação do amado, que registra esse renascimento valendo-se da descrição dos seus trajes:

Fora o acaso ou uma doce inspiração, que arranjara o traje puro e simples que ela trazia? Tudo era branco e resplandecente como a sua fronte serena: por vestes cassas e rendas; por joias somente pérolas. Nem uma fita, nem um aro dourado, manchava essa nítida e cândida imagem. Creio antes na inspiração. [...] Ela me dizia no seu traje, o que nunca se animaria a dizer-me em palavras, que estava tão pura como eu a tinha deixado, do contato de outro homem. (ALENCAR, 2010, p. 87)

As roupas de Lúcia vão fazendo marcadamente a transição do corpo ao espírito no resgate da moça pura. Poderia ter sido outro atributo, outra característica a fazer essa marcação. No entanto, Alencar vale-se da descrição dos trajes e reforça, em Lucíola, o poder de comunicação que eles possibilitam do eu com o mundo externo. Dessa forma - antes um signo da moda do período -, as roupas claras, fluidas, ornadas de rendas e de flores e a delicadeza geral do traje que compunham a toalete das moças da boa sociedade, transformam-se em códigos utilizados pelo escritor para reforçar características psicológicas da sua protagonista, quando essas mesmas descrições dos trajes, no romance, demonstram como esse resgate de personalidade aparecia aos olhos do narrador. "Com a timidez de seu olhar 
velado pelos longos cílios, com o modesto recato de sua graça e o seu vestido de cassa branca, Lúcia parecia-me uma menina de quinze anos, pura e cândida" (ALENCAR, 2010, p. 111).

Nessa transformação da personagem, a austeridade também se abate sobre a caracterização da personagem, externando para o mundo a morte da cortesã e a presença de uma senhora recatada. Vejamos como a descrição a seguir exemplifica essa leitura:

Lúcia trazia nessa manhã um traje quase severo: vestido escuro, afogado e de mangas compridas, com pouca roda, simples colarinho e punhos de linho rebatidos; cabelos negligentemente enrolados em basta madeixa, sem ornato algum. Em vez dos pantufos aveludados que costumava usar em casa, no desalinho, calçava uma botina de merinó preto, que ia-lhe admiravelmente, porque ela tinha o mais lindo pé do mundo. Quando o vento que entrava pela janela erguia indiscretamente a fímbria da saia, apesar do movimento rápido que a aconchegava, descobria-se a volta bordada, de uma calça estreita, cerrando o colo esbelto da perna divina. (ALENCAR, 2010, p. 95)

Na transição da personagem, "o recato austero do traje" é necessário. Ele simbolizava que sua alcova estava vedada, por meio do invólucro material da alma, representado pelas roupas da personagem. Na cortesã, a função do traje era o desnudamento, ainda que, em alguns momentos, de uma nudez velada. A camisola de seda foi substituída pela "longa camisola de linho, sem uma renda, nem um bordado" (ALENCAR, 2010, p. 106). Vemos, ainda, que a transformação da personagem vai ocorrendo não somente no fechamento de seu corpo, mas também em uma atitude de abandono do mundo material e de tudo o que representava o passado de luxo da cortesã. A mudança interna da alma, aos poucos, recai sobre o corpo, simbolicamente, por meio das roupas, dos objetos à sua volta e do isolamento social.

Ainda nesse processo de transição, apesar do desprendimento de Lúcia em relação ao mundo material, que vai aderindo aos poucos, ela conserva as influências de sua vida cortesã, quando percorrera os luxuosos salões da corte. Isto também é expresso em suas roupas, que, apesar da recente austeridade adquirida, "conservava do mundo a elegância e a distinção que se tinha por assim dizer impresso e gravado na sua pessoa" (ALENCAR, 2010, p. 125). Vejamos a descrição dos trajes de Lúcia nos raros passeios que fazia na companhia de Paulo:

O seu traje habitual nestes passeios era vestido de merinó escuro, mantelete de seda preta, e um chapéu de palha com laços azuis. Mas essa mulher tinha a beleza luxuosa que se orna a si mesma, e que os enfeites, longe de realçar, amesquinham, nunca ela me parecia mais linda do que sob essa simplicidade severa. (ALENCAR, 2010, p. 111)

Poderíamos afirmar que essa descrição teria saído da seção de moda de qualquer periódico da corte. Ela descreve muito bem as inúmeras gravuras francesas que circularam no Brasil e distinguiria qualquer dama elegante daquela sociedade. 
Quando Lúcia se redime totalmente da sua vida cortesã, abandona tudo o que essa época passada ofereceu-lhe e vai viver como Maria da Glória com a irmã caçula, isolada em uma chácara retirada da cidade, suas roupas não são mais citadas na narrativa. A transformação havia se consolidado. Tudo o que lhe restava era um "toucador bem pobre e bem modesto, mas ainda assim encantador, como tudo que essa mulher tocava com as pontas de seus dedos de fada ou bafejava com o seu hálito celeste" (ALENCAR, 2010, p. 131). Ela trajava-se de preto para ir à igreja, com véus espessos, sentindo o "quanto é tocante o uso de só penetrar na casa de Deus ocultando a beleza sob a gala triste e grave, que prepara o espírito para o santo recolho" (ALENCAR, 2010, p. 129). E, em casa, retornava de novo às "suas alvas roupas de cassa" (ALENCAR, 2010, p. 129).

\section{Considerações finais}

A relação moda e literatura no romance Lucíola evidencia o poder que as roupas assumem enquanto acessórios da narrativa literária e colaboram com o processo de construção das personagens. Além de conferir verossimilhança à obra, desejo muito perseguido pela literatura romântica do século XIX, a descrição do vestuário oferece ao escritor a possibilidade de criar identidades variadas que, no caso da protagonista do romance de Alencar, oscilava entre um duplo de personalidade, da Maria da Glória à Lúcia e vice-versa.

Em Lucíola, ainda que o texto literário esteja no campo da construção fictícia, foi possível realizar as análises propostas e verificar que as influências externas do meio em que a obra foi produzida, publicada e recebida, oferecem uma relação direta com o seu contexto histórico, econômico e social. Confrontar o romance como texto escrito com as referências de moda da época possibilitam ampliar o diálogo entre moda e literatura, observando como o escritor estava atento às transformações sociais e ao caráter simbólico que as roupas expressavam.

Estudar a moda a partir dos textos literários é buscar indícios de sua importância em diferentes contextos sociais. Assim, a partir de uma pesquisa por teóricos da literatura, da moda, da sociologia e da história, foi possível apresentar um panorama dos costumes de uma sociedade abastada da corte fluminense da segunda metade do século XIX, conforme atestam os exemplos de publicações de jornais da época, afirmando a influência cultural europeia, principalmente a francesa, nos modos e nas modas da elite brasileira do Segundo Reinado.

Por fim, acreditamos ter conseguido estabelecer o diálogo entre moda e literatura presente no romance Lucíola. Por meio de cada passagem, confrontamos a linguagem dos trajes com a caracterização da personagem, tanto nos aspectos físicos quanto na vertente de construção psicológica. Essa afirmação fica mais clara quando visualizamos a importância que a moda assumiu para pontuar a transição da cortesã à moça casta, inferindo a potência dos acessórios da narrativa como elementos de marcação dessa construção literária. 


\section{Referências}

ALENCAR, José de. Lucíola. 2. ed. São Paulo: Martin Claret, 2010.

AZEVEDO, M. de. As luvas. 0 Espelho - Revista de literatura, modas, indústria e artes. Diretor e redator: F. Eleutério de Souza. Ano I, n. 1, 4 set. 1859, p. 7. Rio de Janeiro: Tip. de Paula Brito [e outras]. Disponível em: http://objdigital.bn.br/acervo_digital/div_periodicos/ per700037_contente/index.html. Acesso em: 7 jul. 2019.

BALZAC, Honoré de. Tratados da vida moderna. Trad. Leila de Aguiar Costa. São Paulo: Estação Liberdade, 2009.

BAUDELAIRE, Charles. Sobre a modernidade: o pintor da vida moderna. Org. Teixeira Coelho. Rio de Janeiro: Paz e Terra, 1996.

CANDIDO, Antonio. Literatura e sociedade. 10. ed. Rio de Janeiro: Ouro Sobre Azul, 2008.

CRANE, Diana. A moda e seu papel social: classe, gênero e identidade das roupas. Trad. Cristiana Coimbra. 2. ed. São Paulo: Senac SP, 2006.

CRÔNICA Elegante. 0 Espelho - Revista de literatura, modas, indústria e artes. Diretor e redator: F. Eleutério de Souza. Ano I, n. 1, 4 set. 1859, p. 10. Rio de Janeiro: Tip. de Paula Brito [e outras]. Disponível em: http://objdigital.bn.br/acervo_digital/div_periodicos/ per700037_contente/index.html. Acesso em: 7 jul. 2019.

DE MARCO, Valéria. 0 império da cortesã: Lucíola, um perfil de Alencar. São Paulo: Martins Fontes, 1986.

DUARTE, Cláudia Renata. Textos-tecidos: a moda e a história na literatura. Disponível em: http://ebooks.pucrs.br/edipucrs/Ebooks/Web/978-85-397-0198-8/Trabalhos/22.pdf. Acesso em: 3 out. 2019.

FREYRE, Gilberto. Vida social no Brasil nos meados do século XIX. Recife: Instituto Joaquim Nabuco de Pesquisas Sociais, 1964.

FREYRE, Gilberto. Modos de homem \& modas de mulher. 2 ed. São Paulo: Global, 2009.

GRIFFIN, Susan. O livro das cortesãs: um catálogo das suas virtudes. Trad. Talita M. Rodrigues. Rio de Janeiro: Rocco, 2003.

LAVER, James. A roupa e a moda: uma história concisa. Trad. Glória Maria de Mello Carvalho. São Paulo: Companhia das Letras, 2008. 
M-AS. Revista de teatros. 0 Espelho - Revista de literatura, modas, indústria e artes. Diretor e redator: F. Eleutério de Souza. Ano I, n. 4, 25 set. 1859, p. 8. Rio de Janeiro: Tip. de Paula Brito [e outras]. Disponível em: http://objdigital.bn.br/acervo_digital/div_periodicos/ per700037_contente/index.html. Acesso em: 7 jul. 2019.

MACEDO, Joaquim Manuel de. Memórias da Rua do Ouvidor. Brasília: UnB, 1988.

MENEZES, Lená Medeiros de. Francesas no Rio de Janeiro: modernização e trabalho segundo o Almanak Laemmert (1844-1861). Disponível em: http://www.labimi.uerj.br/ artigos/1306519921.pdf. Acesso em: 13 set. 2019.

MURICY, Kátia. A razão cética. São Paulo: Cia das Letras, 1988.

PINHO, Wanderley. Salões e damas do Segundo Reinado. 2. ed. São Paulo: Martins, 1942.

RAINHO, Maria do Carmo Teixeira. A cidade e a moda: novas pretensões, novas distinções - Rio de Janeiro, século XIX. Brasília: UnB, 2002.

REUTER, Yves. A análise da narrativa: o texto, a ficção e a narração. Trad. Mário Pontes. 2. ed. Rio de Janeiro: Difel, 2007.

RODRIGUES, Mariana Christina de Faria Tavares. Mancebos e mocinhas: moda na literatura brasileira do século XIX. São Paulo: Estação das Letras e Cores, 2010.

SALOMON, Geanneti Tavares. Moda e ironia em Dom Casmurro. São Paulo: Alameda, 2010.

SOUZA, Gilda de Mello e. 0 espírito das roupas: a moda no século XIX. 6. ed. São Paulo: Companhia das Letras, 2009. 